\title{
Evaluation of sour cherry varieties grown with environmental technology
}

\author{
Felföldi, J. ${ }^{1}$, Szabó, T. ${ }^{2}$, Nyéki, J. ${ }^{3}$, Szabó, Z. ${ }^{3}$, Soltész, M. ${ }^{3}$ \& Apáti, F. ${ }^{1}$ \\ ${ }^{1}$ University of Debrecen, Dept. Agrobusiness, Management \\ ${ }^{2}$ Fruit Growing Station Ltd. Újfehértó \\ ${ }^{3}$ University of Debrecen, Institute for Research and Development
}

\begin{abstract}
Summary: The evaluation of a produce is an important moment of predicting its success on the market. The general impression, which is decisive, when a consumer chooses to purchase the commodity, should be interpreted in more objective, measurable terms. Primary data have been collected on fresh fruits derived from different growing technologies by organoleptic tests and the data filled up in the forms are processed with correlation analysis. The components were: taste, aroma, flesh firmness. The coefficients of correlation showed that the rest of characters as the appearance, juiciness, and the sugar/acid ratio.
\end{abstract}

Key words: sour cherry, environmental technology, fresh consumption, fruit-characters

\section{Introduction}

Primary data are derived from observation or measurement, but also collected from answering persons dealing with the object. The entrepreneurs of this branch of horticulture do not dispose of sufficient monetary power to gather objective information of the popularity of their produces, we undertook to perform this task. The attitudes of Hungarian consumers' to fruits offered on the market have been published by Felföldi et al. (2008). Further results regarding the consumption of apples are found in papers of Vanczák et al. (2002) and Gonda et al. (2007) dealing with earlier years. We may also learn about the role of conscientious attitudes by the consumers (TNS, 2009). The future of the fruit growing branch is dealt with by Apáti \& Gonda (2010), and about the outlooks concerning stone fruits by Szabó et al. (2010).

Our objective is to multiply the information referring to the fresh consumption of sour cherry from primary sources. The objectives are:

The sour cherry grown by environmental (ecological) technology are examined for the following six properties: flesh firmness, juiciness, sugar/acid ratio, aroma (flavour), taste and outer appearance. Furthermore, the correlation between the six properties and the "general impression" has been calculated (estimated), the latter being decisive as the attitude of the consumer.

\section{Materials and methods}

Answer given to a question is an information, which cannot be substituted by any other method only approached (Hoffmann et al. 2001). We evaluated the answers given by persons of the organoleptic panel. The fruits have been supplied by the Station of Ujfehértó in 2009. The panel tested 16 sour cherry varieties and expressed its opinion by filling out a form. Each 6 property received a number of the scale $0-9$, moreover the seventh property was the "general impression". The test has been performed at three independent opportunities and each time the session lasted 2-3 hours in order to avoid boredom. The data of the forms have been processed by correlation analysis.

\section{Results}

The coefficient of variation (cv) varied between 3 and $8 \%$, except two varieties: Érdi jubileum and VN-1-0608. The judgement of the varieties was surprisingly uniform for all 6 properties. The cv of VN-1-0608 was 12\% and of Érdi jubileum $\mathrm{cv}=17 \%$. The two variety received very different point by the members of the panel. Most diverse points are given for the sugar/acid ratio and for juiciness in the case of the two varieties mentioned.

The firmness of Érdi jubileum was outstanding as the average was more than 7 . The nearest were VN-1-0608. Pándi and VN-4-0624 with 6 point as a mean. The less firm were VN-7-0701, L-0701 and Csengödi-0701, having 3.2-3.6 points. In juisiness VN-7-0701, Csengődi-701 and L0701 received the highest values 6.7-6.9. Lowest values received VN-4-0701 and VN-1-0608 with 4.8 and 5.3 points. Highest values of sugar/acid ratio are given to A-0701 and high values also Debreceni bőtermő, M-0701 and Körösi korai, their values were 6.3-6.9 as a mean. The aroma (flavour) was best in VN-1-0608 and Korai pipacs wit means above 6 points. The same two varieties received the best 
Table 1. The coefficients of variation of the values given the sour cherry varieties

\begin{tabular}{|l|c|c|c|c|c|c|c|}
\hline Variety & $\begin{array}{c}\text { Flesh } \\
\text { firmness }\end{array}$ & Juiciness & $\begin{array}{c}\text { Sugar/ } \\
\text { acid }\end{array}$ & Aroma & $\begin{array}{c}\text { Appe- } \\
\text { arance }\end{array}$ & Taste & $\begin{array}{c}\text { General } \\
\text { impression }\end{array}$ \\
\hline Érdi jubileum-0608 & 8.06 & 22.92 & 22.47 & 27.19 & 14.60 & 21.53 & 16.94 \\
\hline VN-1-0608 & 15.55 & 26.92 & 24.74 & 21.53 & 13.92 & 18.66 & 12.18 \\
\hline Korai pipacs-0624 & 5.67 & 6.07 & 5.67 & 6.20 & 5.80 & 7.13 & 6.67 \\
\hline VN-4-0624 & 5.93 & 5.40 & 5.13 & 5.93 & 6.33 & 6.33 & 6.33 \\
\hline Csengödi-0624 & 5.27 & 5.67 & 5.93 & 5.67 & 6.73 & 6.47 & 6.67 \\
\hline Körösi korai-0624 & 4.20 & 5.80 & 6.33 & 5.13 & 6.07 & 6.60 & 6.53 \\
\hline Pándi 48-0701 & 5.95 & 5.74 & 6.05 & 4.89 & 6.26 & 5.74 & 5.95 \\
\hline Csengödi-0701 & 3.63 & 6.68 & 3.84 & 5.21 & 5.74 & 6.47 & 6.11 \\
\hline Debreceni bötermö-0701 & 4.68 & 5.95 & 6.89 & 4.89 & 7.11 & 4.68 & 5.53 \\
\hline VN-4-0701 & 5.63 & 4.79 & 4.37 & 5.32 & 5.00 & 5.63 & 5.37 \\
\hline VN-7-0701 & 3.22 & 6.89 & 5.67 & 5.33 & 5.89 & 6.00 & 5.94 \\
\hline A-0701 & 4.05 & 6.37 & 7.63 & 5.42 & 6.37 & 5.53 & 5.47 \\
\hline E-0701 & 5.00 & 6.11 & 5.78 & 5.61 & 7.11 & 6.44 & 6.17 \\
\hline $\boldsymbol{M - 0 7 0 1}$ & 5.22 & 6.00 & 6.56 & 5.11 & 7.00 & 5.44 & 5.72 \\
\hline $\boldsymbol{N - 2 - 0 7 0 1}$ & 4.78 & 6.00 & 4.00 & 5.28 & 5.00 & 6.00 & 5.89 \\
\hline L-0701 & 3.33 & 6.67 & 4.33 & 5.33 & 6.44 & 6.67 & 6.44 \\
\hline
\end{tabular}

Source: original data scores in taste, i.e. more than 7.1 points. The best appearance was displayed by three varieties as Debreceni bőtermő, E-0701 and M-0701.

The scores of general impression have been shown in Figure 1. Highest (>6.5) mean scores received Körösi korai-0624, Csengődi-0624, Korai pipacs-0624 and more than 7.00 scores VN-1-0608. The lowest score (5.37) was given to $\mathrm{VN}-4-0701$.

The firmness of flesh, juiciness, sugar/acid ratio, appearance of the fruits alone were not sufficient to determine the general impression. The simple coefficients of correlation between the scores of individual properties are visible in Table 2. The value of the coefficient of correlation was lower than $r=0.25$. Flesh firmness and general impression had $\mathrm{r}=0.22$,

Table 2. The relation of the individual properties between each other and the general impression

\begin{tabular}{|c|c|c|c|c|c|c|c|c|}
\hline & Kendall's tau_b & $\begin{array}{c}\text { Flesh } \\
\text { firmness }\end{array}$ & Juiciness & $\begin{array}{c}\text { Sugar/acid } \\
\text { Ratio }\end{array}$ & Aroma & Appearance & Taste & $\begin{array}{c}\text { General } \\
\text { impression }\end{array}$ \\
\hline \multirow[t]{3}{*}{ Flesh firmness } & $\begin{array}{l}\text { Correlation } \\
\text { Coefficient }\end{array}$ & 1.00 & -0.56 & 0.01 & 0.29 & -0.07 & 0.16 & 0.22 \\
\hline & Sig. (2-tailed) & . & 0.00 & 0.96 & 0.13 & 0.72 & 0.39 & 0.24 \\
\hline & $\mathrm{N}$ & 16.00 & 16.00 & 16.00 & 16.00 & 16.00 & 16.00 & 16.00 \\
\hline \multirow[t]{3}{*}{ Juiciness } & $\begin{array}{l}\text { Correlation } \\
\text { Coefficient }\end{array}$ & -0.56 & 1.00 & 0.03 & -0.13 & -0.01 & 0.00 & -0.16 \\
\hline & Sig. (2-tailed) & 0.00 & . & 0.86 & 0.50 & 0.96 & 1.00 & 0.39 \\
\hline & $\mathrm{N}$ & 16.00 & 16.00 & 16.00 & 16.00 & 16.00 & 16.00 & 16.00 \\
\hline \multirow[t]{3}{*}{ Sugar/acid Ratio } & $\begin{array}{l}\text { Correlation } \\
\text { Coefficient }\end{array}$ & 0.01 & 0.03 & 1.00 & -0.14 & 0.35 & -0.29 & -0.19 \\
\hline & Sig. (2-tailed) & 0.96 & 0.86 & . & 0.44 & 0.06 & 0.12 & 0.30 \\
\hline & $\mathrm{N}$ & 16.00 & 16.00 & 16.00 & 16.00 & 16.00 & 16.00 & 16.00 \\
\hline \multirow[t]{3}{*}{ Aroma } & $\begin{array}{l}\text { Correlation } \\
\text { Coefficient }\end{array}$ & 0.29 & -0.13 & -0.14 & 1.00 & -0.03 & 0.50 & 0.46 \\
\hline & Sig. (2-tailed) & 0.13 & 0.50 & 0.44 & . & 0.86 & 0.01 & 0.01 \\
\hline & $\mathrm{N}$ & 16.00 & 16.00 & 16.00 & 16.00 & 16.00 & 16.00 & 16.00 \\
\hline \multirow[t]{3}{*}{ Appearance } & $\begin{array}{l}\text { Correlation } \\
\text { Coefficient }\end{array}$ & -0.07 & -0.01 & 0.35 & -0.03 & 1.00 & -0.13 & 0.10 \\
\hline & Sig. (2-tailed) & 0.72 & 0.96 & 0.06 & 0.86 & . & 0.50 & 0.59 \\
\hline & $\mathrm{N}$ & 16.00 & 16.00 & 16.00 & 16.00 & 16.00 & 16.00 & 16.00 \\
\hline \multirow[t]{3}{*}{ Taste } & $\begin{array}{l}\text { Correlation } \\
\text { Coefficient }\end{array}$ & 0.16 & 0.00 & -0.29 & 0.50 & -0.13 & 1.00 & 0.72 \\
\hline & Sig. (2-tailed) & 0.39 & 1.00 & 0.12 & 0.01 & 0.50 & . & 0.00 \\
\hline & $\mathrm{N}$ & 16.00 & 16.00 & 16.00 & 16.00 & 16.00 & 16.00 & 16.00 \\
\hline \multirow[t]{3}{*}{ General impression } & $\begin{array}{l}\text { Correlation } \\
\text { Coefficient }\end{array}$ & 0.22 & -0.16 & -0.19 & 0.46 & 0.10 & 0.72 & 1.00 \\
\hline & Sig. (2-tailed) & 0.24 & 0.39 & 0.30 & 0.01 & 0.59 & 0.00 & . \\
\hline & $\mathrm{N}$ & 16.00 & 16.00 & 16.00 & 16.00 & 16.00 & 16.00 & 16.00 \\
\hline
\end{tabular}

\footnotetext{
** Correlation issignificant at the 0.01 level (2-tailed)

* Correlation issignificant at the 0.05 level (2-tailed)

Source: original data
} 


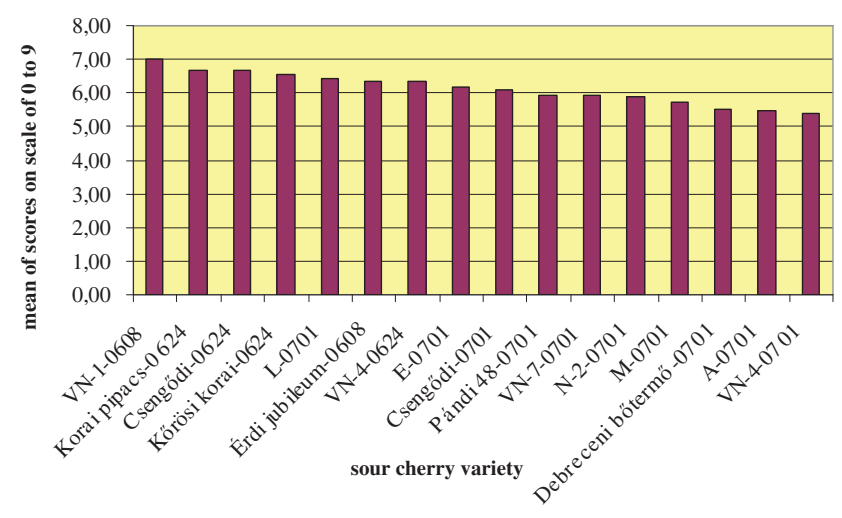

Figure 1. The mean scores given to sour cherry varieties as for their general impression

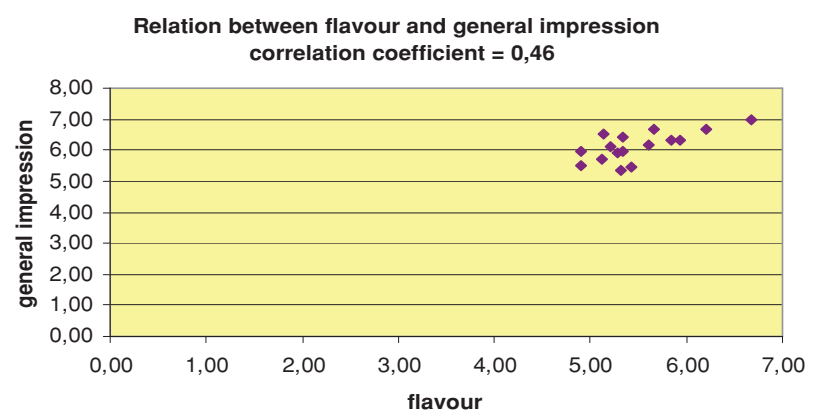

Source: original data

Figure 2. Relation between flavour and general impression of sour cherry varieties

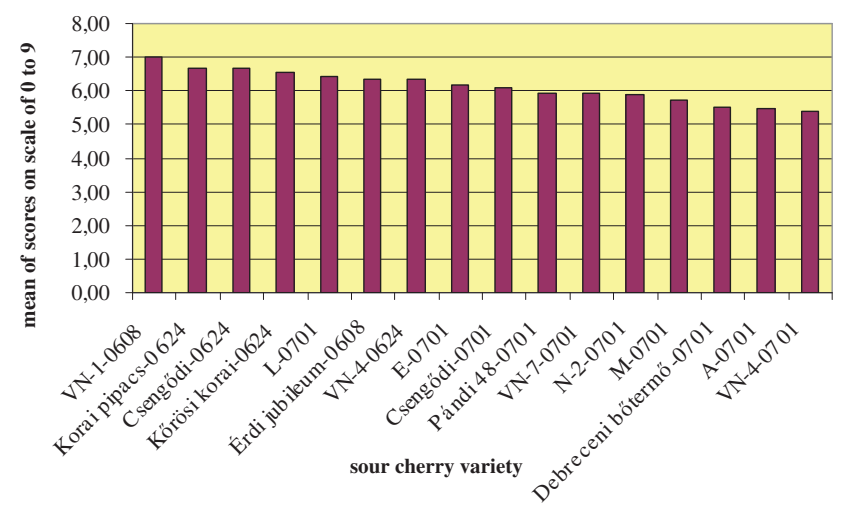

Source: original data

Figure 3. Relation between taste and general impression of sour cherry varieties

juiciness and general impression: $\mathrm{r}=-0.16$, sugar/acid ratio and general impression: $\mathrm{r}=-0.19$, the appearance and the general impression $r=0.10$. All those correlations are very weak.
Significant correlation was found between aroma (flavour) and taste $(\mathrm{r}=0.5)$ and between aroma and general impression ( $\mathrm{r}=0.46)$ as in Figure 2. The most significant is between taste and general impression $(r=0.72)$ in Figure 3 . Those are mediocre and strong correlations, respectively.

\section{Conclusions}

Among the properties examined two, flesh firmness and juiciness, are pointed out as being related to each other on a mediocre level, negatively. As a consequence, the firm flesh and juiciness are opposite grades. Four from the six examined properties, firmness, juiciness, sugar/acid ratio and appearance alone could not influence the general impression, the seventh but most decisive property. Two properties, aroma (flavour) and taste are correlated with one another on a mediocre and strong positive level. Nevertheless, general impression is most dependent on the taste and flavour.

\section{Acknowledgement}

This paper was supported by the János Bolyai Research Scholarship of the Hungarian Academy of Sciences

\section{References}

Apáti, F. \& Gonda, I. (2010): The future of the Hungarian sour cherry growing branch. International Journal of Horticultural Science. 16. (1): 99-104.

Felföldi, J., Apáti, F., Szabó, V. \& Nábrádi, A. (2008): Fogyasztói attitüdök az almapiacon. Élelmiszer, Táplálkozás és Marketing The Hungarian Journal of Food, Nutrition and Marketing. 5. (2-3): 87-92.

Gonda, I., Dremák, P., Vaszily, B. \& Rakonczás, N. (2007): Marketingprogram kidolgozása a hazai frissalma fogyasztás növelése érdekében (Kutatási jelentés)

Hoffmann, M., Veres, Z. \& Kozák, Á. (2001): Piackutatás. Müszaki Kiadó, Budapest

Szabó, Z., Soltész, M., Apáti, F. \& Nyéki, J. (2010): Conditions and outlooks of growing stone fruits. International Journal of Horticultural Science. 16. (1): 91-98.

TNS (2009): Vásárlói tudatosság. Progresszív Magazin. Crier Media Csoport. 17. (4): 50. p.

Vanczák, E., Takácsné György, K. \& Komáromi, N. (2002): A gyümölcs- és almafogyasztás helyzete, egy kérdőíves felmérés eredményei. Kertgazdaság. 34. (2): 55-60. 